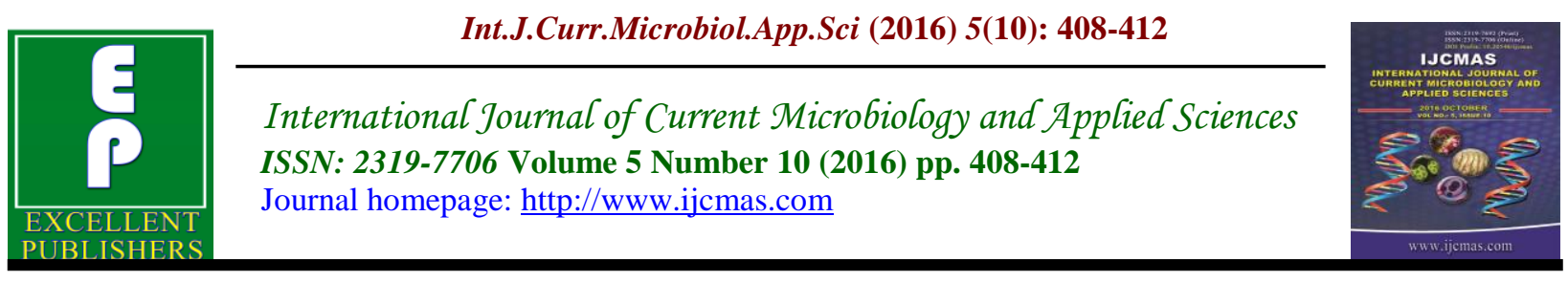

Original Research Article

http://dx.doi.org/10.20546/ijcmas.2016.510.046

\title{
Are Multi-dose Vials Safe for BCG Vaccination of Infants? A Study to Focus on the Microbial Elements of Contamination in a Tertiary Care Hospital of West Bengal, India
}

\author{
Nikhil Kumar Tudu ${ }^{1}$, Aditya Prasad Sarkar ${ }^{2 *}$ and Tapan Kumar Chatterjee ${ }^{3}$ \\ ${ }^{1}$ Department of Microbiology, Bankura Sammilani Medical College, \\ Bankura, West Bengal, India \\ ${ }^{2}$ Department of Community Medicine, Bankura Sammilani Medical College, \\ Bankura, West Bengal, India \\ ${ }^{3}$ Department of Department of Microbiology, Bankura Sammilani Medical College, \\ West Bengal, India \\ *Corresponding author
}

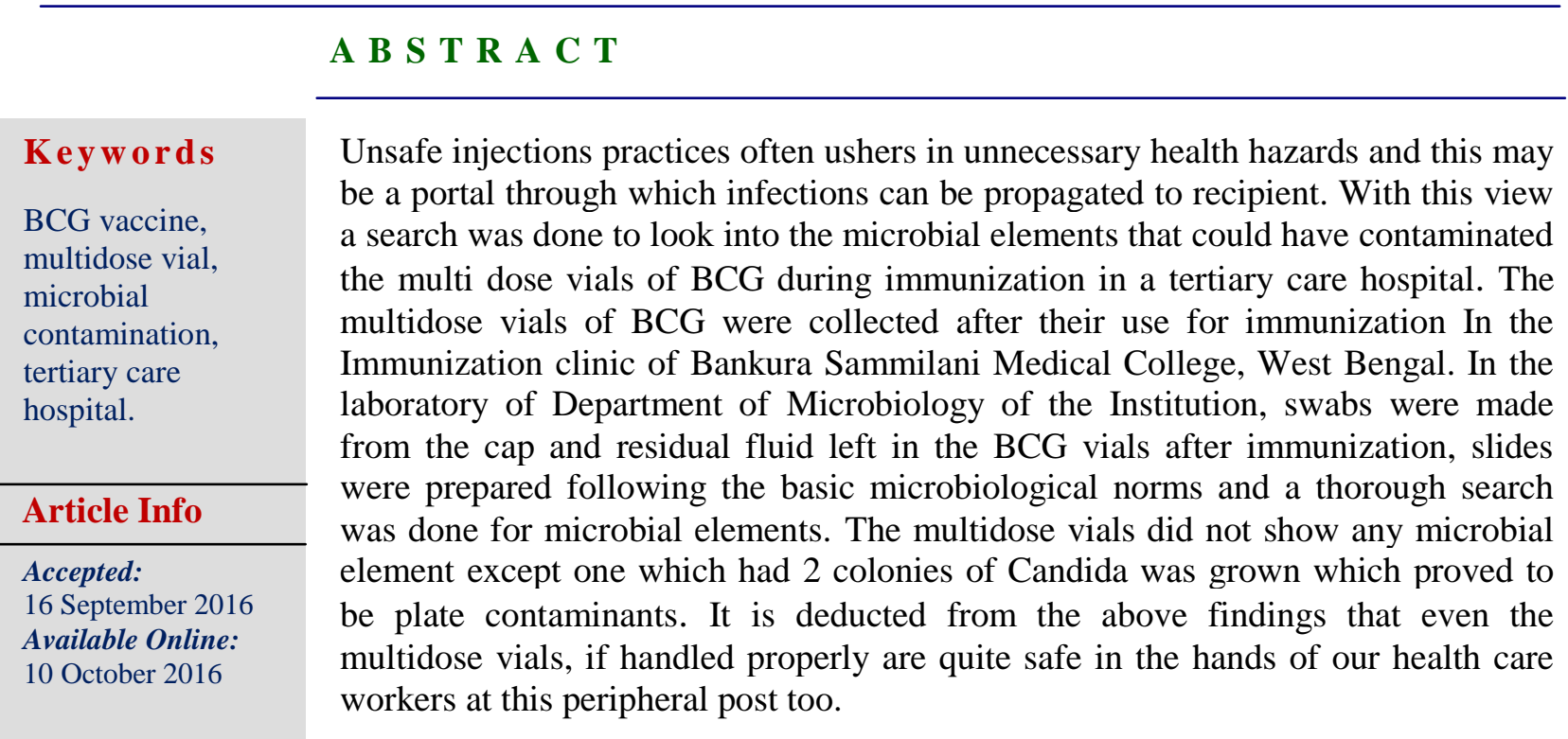

\section{Introduction}

More than 150,000 patients have been impacted by unsafe medical injections since 2001 (The Impact of Unsafe Injection Practices in U.S. Healthcare Settings). Breakdowns in proper infection control practices often involve providers reusing needles, syringes in single-dose medication vials, all of which are meant for one patient and one procedure. The chances of bacterial contamination becomes more in case of multi dose vials which are used for vaccination and for parenteral antibiotic injections These breaches in safe injection practices can cause irreparable damage, exposing patients to blood borne illnesses such as hepatitis B , C and HIV, and to lifethreatening bacterial infections. Although safe injection practices represent very basic 
infection control measures, the Center for Disease Control and Prevention (CDC) routinely identifies and investigates outbreaks associated with deficient practices and sends routine guidelines for use in different hospital worldwide.

Multiple-dose vials (MDV) are vials in which antibacterials/ vaccine preparations are present and may be used more than once based as per the manufacturer's recommendations (Dade et al., 2000). Single-dose vials (SDV) are intended to be used only once. There is possibility of microbial contamination of any SDVs, and MDVs.

It has been demonstrated that potentially pathogenic microorganisms can survive and sometimes proliferate in MDVs, Which in turn creates a potential risk for parenteral inoculation of pathogenic organisms.

Known Factors that might affect the quality and sterility of the medication are as follows: number of withdrawals made from the vial, sterility of the techniques employed by the health care personnel, injection of environmental air into the vial during extraction, duration of use and storage, conditions of container storage (temperature, sun exposure, and others), and the presence or absence of preservatives in the vial (Plott et al., 1990; Stolar, 1980). Drugs without preservative and drugs containing lipids are more prone to contamination (Mattner et al., 2004).

It was reported that the administration of contaminated MDVs, with Pseudomonas aeruginosa, Enterobacter cloacae, Candida albicans and Serratia marcescens have resulted in several cases of bloodstream infection, bacterial meningitides, wound infection and even death in the receiving patients (Archibald et al., 1998; Tresoldi et al., 2000).
BCG vials containing BCG vaccine for percutaneous use, are an attenuated live culture preparations of the Bacillus of Calmette and Guerin (BCG) strain of Mycobacterium bovis, strains are attenuated and have lost their ability to cause disease in humans.

Because the living bacilli evolve to make the best use of available nutrients, they become less well-adapted to human blood and can no longer induce disease when introduced into a human host. Still, they are similar enough to their wild ancestors to provide some degree of immunity against human tuberculosis. The BCG vaccine is effective in preventing tuberculosis for a duration of 15 years; however, its protective effect appears to vary according to geography and the lab in which the vaccine strain was grown. This may again be due to different genetic variations in the bacillus.

A number of different companies make BCG, sometimes using different genetic strains of the bacterium. The freeze-dried BCG preparation is delivered in vials, each containing 1 to $8 \times 10^{8}$ colony forming units (CFU) of $\mathrm{BCG}$ which is equivalent to approximately $50 \mathrm{mg}$ wet weight.

Determination of in-vitro potency is achieved through colony counts derived from a serial dilution assay. Intra-dermal guinea pig testing is also used as an indirect measure of potency. Reconstitution requires addition of Sterile Water for Injection, U.S.P. at $4-25^{\circ} \mathrm{C}\left(39-77^{\circ} \mathrm{F}\right)$. For an adult dosage, $1 \mathrm{~mL}$ of Sterile Water for Injection, U.S.P., should be added to one vial of vaccine. For a pediatric dosage, $2 \mathrm{~mL}$ of Sterile Water for Injection, U.S.P., should be added to one vial of vaccine. No preservatives have been added. The vials thus contain a protein, a sugar sometimes lactose, and having no preservatives. 
The policy is to discard the solution after 6 hours or at the end of immunization and whichever is less. Because of the contents of ingredients, the exposure these vials may get from atmosphere and a situation of no preservative and moreover addition of lactose can invite multiple pathogens logically.

With this background the present study was conducted to investigate the magnitude and pattern of microbial contamination of MDVs which were used for BCG vaccination in a tertiary level health care institution of West Bengal.

\section{Materials and Methods}

Without prior warning, opened vials of MDVs in the Department of Community Medicine, Bankura Sammilani Medical College, Bankura, West Bengal which were going to be reused by nursing staff were collected.

The related information such as the drug type, production date, expiration date, first day of vials opening, labelling of vials and storage conditions were recorded. Characteristics of samples are shown in table 1. Samples were transferred to the laboratory of Department of Microbiology, Bankura Sammilani Medical College, Bankura, West Bengal and analysis was started immediately. Prior to sampling, the vials were shaken vigorously and the gums were swabbed with70\% ethyl alcohol.

\section{Microbiological diagnosis tests}

The vials collected on different dates as depicted in the table were first observed macroscopically for features of bacterial contamination like turbidity, granular deposits, membrane formation or production of gas bubbles etc.A gram stain preparation was done to look for any gram positive or gram negative organism from the upper surface of the vial as well as from the fluid which remained after use.

Then a swab was taken from the upper surface of the vial as well as a portion of the fluid. This was inoculated into MacConkeys medium as well as into blood agar medium. Lastly some of the residual portion was inoculated into Robertson's cooked meat broth to look for anaerobes if any.

\section{Main outcome measures}

(1) Visual inspection for debris, medication type, location, lot number, manufacturer's expiration date, and date of opening; (2) culture in solid and broth media for bacterial growth; and (3) staining and microscopic examination for cellular constituents.

\section{Results and Discussion}

The rate of admixture vials and MDVs contamination was reported in range of 0 $14.5 \%$ and $0-27 \%$, respectively in various studies. But the present study revealed no such contamination except Candida in one vial as plate contaminant. Thus the study showed that

1. The immunization work was done satisfactorily maintaining aseptic condition.

2. No vial had any bacterial/ fungal contamination except in one which had an yield of Candidaspecies as the plate contaminant.

3. The multidose vials if properly handled with due precautions is not hazardous for immunization even in the peripheral Medical colleges. 
Table.1 Particulars of the vials tested

\begin{tabular}{|c|c|c|c|l|c|c|}
\hline $\begin{array}{l}\text { Vial } \\
\text { no. }\end{array}$ & Manufacturer & $\begin{array}{l}\text { Production } \\
\text { date }\end{array}$ & $\begin{array}{l}\text { Expiration } \\
\text { date }\end{array}$ & $\begin{array}{l}\text { Date on } \\
\text { which vials } \\
\text { opened }\end{array}$ & Batch No. & $\begin{array}{l}\text { Storage } \\
\text { conditions }\end{array}$ \\
\hline 1 & $\begin{array}{l}\text { Serum Institute of } \\
\text { India Limited }\end{array}$ & June 2014 & May 2016 & $04 / 01 / 16$ & $37 \mathrm{G} 4092 \mathrm{O}$ & $2^{0}-8^{0} \mathrm{C}$ \\
\hline 2 & do & June 2015 & May 2017 & $22 / 01 / 16$ & $37 \mathrm{G} 5119 \mathrm{M}$ & do \\
\hline 3 & do & do & Do & $10 / 02 / 16$ & do & do \\
\hline 4 & do & do & Do & $04 / 03 / 16$ & do & do \\
\hline 5 & do & do & Do & $21 / 03 / 16$ & do & do \\
\hline 6 & do & do & Do & $06 / 04 / 16$ & do & do \\
\hline 7 & do & do & Do & $11 / 05 / 16$ & do & do \\
\hline 8 & do & do & Do & $27 / 05 / 16$ & do & do \\
\hline 9 & do & do & Do & $08 / 06 / 16$ & do & do \\
\hline 10 & do & do & Do & $29 / 06 / 16$ & do & do \\
\hline
\end{tabular}

Table. 2 Culture report of swabs taken from vials

\begin{tabular}{|l|l|l|l|l|l|}
\hline Lot no. & $\begin{array}{l}\text { Media used/ } \\
\text { Swabs collected }\end{array}$ & $\begin{array}{l}\text { Growth } \\
\text { after 24 } \\
\text { hours }\end{array}$ & $\begin{array}{l}\text { Growth } \\
\text { after 72 } \\
\text { hours }\end{array}$ & $\begin{array}{l}\text { Growth in } \\
\text { SDA after } \\
\text { 7days }\end{array}$ & $\begin{array}{l}\text { Robertson's } \\
\text { CookedMeatBroth }\end{array}$ \\
\hline $1^{\text {st }}$ lot & $\begin{array}{l}\text { MacConkeys/ } \\
\text { blood agar/SDA } \\
\text { medium with } \\
\text { antibiotics } \\
2 \text { swabs }\end{array}$ & Nil & Nil & Nil & Nil \\
\hline $2^{\text {nd }}$ lot & Do & Nil & Nil & Nil & Nil \\
\hline $3^{\text {rd } l \text { lot }}$ & Do & Nil & Nil & $\begin{array}{l}\text { Growth of } \\
\text { colonies } \\
\text { of Candida }\end{array}$ & Nil \\
\hline $4^{\text {th } l o t}$ & Do & Nil & Nil & Nil & Nil \\
\hline $5^{\text {th } l o t}$ & Do & Nil & Nil & Nil & Nil \\
\hline $6^{\text {th } l \text { ot }}$ & Do & Nil & Nil & Nil & Nil \\
\hline $7^{\text {th } 1 \text { ot }}$ & Do & Nil & Nil & Nil & Nil \\
\hline $8^{\text {th } l o t}$ & Do & Nil & Nil & Nil & Nil \\
\hline $9^{\text {th } l \text { tot }}$ & Do & Nil & Nil & Nil & Nil \\
\hline $10^{\text {th }}$ lot & Do & Nil & Nil & Nil & Nil \\
\hline & & & & & \\
\hline
\end{tabular}

In conclusion, transmission of infection via contaminated MDVs has been well documented and contamination with fungal/ bacterial or chemical agents is a possibility. Recommendations include dating MDVs after opening, emphasizing the need for proper aseptic technique, and discarding
MDVs on the manufacture's date of expiration. These recommendations if properly followed can eliminate the chance contaminations .It is a good sign for maintenance of aseptic procedures by our health care workers, This study invites an extension where by the parenteral fluids/ 
multidose antibiotic vials/ and single dose vials are to be observed for microbial contamination.

\section{References}

Archibald, L.K., Ramos, M., Arduino, M.J., Aguero, S.M., Deseda, C., Banerjee, S., Jarvis, W.R. 1998. Enterobacter cloacae and Pseudomonas aeruginosa polymicrobial bloodstream infections traced to extrinsic contamination of a dextrose multidose vial. $J$. Pediatr., 133: 640-44.

Dade, J., Wilcox, M., Kay, L. 2000. Hazards of multiple use of pharmaceutical solutions. Lancet, 356: 1684-85.

Longfield, R.N., Smith, L.P., Longfield, J.N., Coberly, J., Cruess, D. 1985. Multiple-dose vials: persistence of bacterial contaminants and infection control implications. Infect. Control, 6: 194-99.

Mattner, F., Gastmeier, P. 2004. Bacterial contamination of multiple-dose vials: a prevalence study. Am. J. Infect. Control, 32: 12-169.

Mattner, F., Gastmeier, P. 2004. Microbial contamination of multiple-dose vials: a prevalence study. Am. J. Infect. Control, 32: 13-16.

Plott, R.T., Wagner, R.F. Jr, Tyring, S.K.1990. Iatrogenic contamination of multidose vials in simulated use: a reassessment of current patient injection technique. Arch. Dermatol., 126: $1441-44$.

Stolar, M.H. 1980. Multiple-dose vials. Am. J. Hosp. Pharm., 37: 185-90.

The Impact of Unsafe Injection Practices in U.S. Healthcare Settings, CDC News Room, Digital Press Kit, Centers for Disease Control and Prevention Atlanta.

Thomas, M., Sanborn, M.D., Couldry, R. 2005. IV admixture contamination rates: traditional practice site versus a class 1000 clean room. Am. J. HealthSyst. Pharm., 62: 2386-92.

Tresoldi, A.T., Padoveze, M.C., Trabasso, P., Veiga, J.F., Marba, S.T., von Nowakonski, A., Branchini, M.L. 2000. Enterobacter cloacae sepsis outbreak in a newborn unit caused by contaminated total parenteral nutrition solution. Am. J. Infect. Control, 28: 258-61.

\section{How to cite this article:}

Nikhil Kumar Tudu, Aditya Prasad Sarkar and Tapan Kumar Chatterjee. 2016. Are Multi-dose Vials Safe for BCG Vaccinationof Infants? A Study to Focus on the Microbial Elements of Contamination in a Tertiary Care Hospital of West Bengal, India. Int.J.Curr.Microbiol.App.Sci. 5(10): 408-412. doi: http://dx.doi.org/10.20546/ijcmas.2016.510.046 